\title{
IMPACT OF OFFICIAL DEVELOPMENT ASSISTANCE ON SUSTAINABLE DEVELOPMENT OF PAKISTAN
}

\author{
Fouzia Perveen \\ Department of Economics \\ Faculty of Business Administration \\ Mohammad Ali Jinnah University, Karachi, Pakistan \\ E-mail:p.fouzi@yahoo.com \\ Afaq Ali Khan \\ Department of Economics \\ Faculty of Business Administration \\ Mohammad Ali Jinnah University, Karachi, Pakistan
}

\begin{abstract}
This research paper aims to find out the relationship between Official Development Assistance and sustainable development in Pakistan. Time series data was taken for the period of 42 years (19762017). Sustainable Development is a dependent variable for which proxy variable of Adjusted Net Savings has been deployed. ODA (\% of GNI), Inflation, Per Capita GDP and Trade (GDP \%) have been used as explanatory variables. Augmented Dickey-Fuller Test has been applied to examine the nature of the data as time series data may contain unit root problems. ADF test confirms mixed order of integration for the selected variables, hence Autoregressive Distributed Lag (ARDL) Approach was applied to find out the long-run relationship among the considered variables. Estimation of Error Correction Regression resulted in a significant long-run relationship between ODA and Sustainable Development. ECM Regression also signifies the negative and significant value of the speed of adjustment term confirming that the model is stable and convergent towards the equilibrium. Overall results of this study confirm a positive and highly significant relationship between ODA and the measure of sustainable development in Pakistan. Therefore it is recommended that attention should be given to drawing on foreign assistance and it should be subject to the transparent and efficient practices applied in the Aid Allocation. It significantly improves the overall welfare of Pakistan.
\end{abstract}

Keywords: Official Development Assistance, Sustainable Development, Adjusted Net Savings.

\section{INTRODUCTION}

Development Assistance Committee of the Organization for Economic Cooperation and Development (OECD) introduced the terminology of Official Development Assistance (ODA) for the foreign funding transferred to developing countries. (Radelet, 2006) Foreign inflows normally include non-repayable grants, soft loans with tight conditions, project and non-project assistance, technical backing and relief aid packages (natural disaster relief packages) foreign direct investment, credit for BOP imbalance etc. Foreign aid may be granted by multilateral institutions, like IMF, World Bank, Agriculture Organization and OECD etc. and the resources are transferred from institutions to the Government of developing countries. In addition to that, some regional 
institutions such as; the Asian Development Bank, the Inter-American Development Bank, SAARC, the European Union, Common Wealth etc. also support their regional countries. (Husain, 2005).

Development studies have identified, the low level of domestic savings serves as a bigger challenge for the pace of the economic growth of developing countries. It is taken to be a big barrier in the growth rate of capital accumulation to meet the underlying investment opportunities and accelerate the pace of economic development. Hence, it becomes challenging for the developing countries to put the economy on the path of sustainable growth rates. External resources transferred to the poor countries can fill twin gaps; foreign exchange gap and also saving gap (Papanek, 1973).

This study investigates the impact of foreign aid and sustainable development of Pakistan across the period of 1976-2017. The motivation behind this verification lies in two grounds:

- The obvious research gap in the previous literature published on the effectiveness of Aid in the scenario of Pakistan. The traditional studies while investigating the "effectiveness" of the foreign aid inflows deploy the indicator of GDP growth rate which is not the real representative of the sustainable development and does not present the holistic impact of the foreign aid impact on the economic, social and environmental indicators.

- The post-2015 paradigm shift of the development efforts focusing on Sustainable Development serves a policy relevance. World Leaders are agreed to follow the new agenda of International Development, "Transforming our World: The 2030 Agenda for Sustainable Development" organized in the general assembly of the US on September 25, 2015. Under this agenda, 17 goals of Sustainable Development known as SDGs are embraced by all the Member countries of UNO, as an agenda of 2030.

While discussing the role of foreign inflows in Pakistan Husain (2005) highlighted the role of three leading multilateral institutions i-e. IMF, World Bank and the ADB provide a credit on soft and hard conditions, depending upon the nature of the financing. He mentioned in his lecture, the core function of IMF is to provide support to countries that face the problem of Balance of Payment deficits. But, The World Bank and ADB are development banks dedicatedly established to reduce poverty and uplift the living standards of the people of developing countries having the low pace of economic growth. Nonetheless, these aid agencies share a common goal of boosting economic growth and cut down the unemployment rate in the Aidrecipient country. During the era of the 1960s, under the idea of Growth Manship growth target was set to be at $6 \%$ double of the population rate of that time, to keep the country on stability path. (Mohey-ud-din, 2005)

The financing of physical infrastructure projects like power and irrigation projects which laid down the foundation of the economic growth in the country could be a dream without external funding. [See: Malik et al. 1994; Salman \& Hui, 2009]

The below figure shows the savings-investment gap in Pakistan from 1976 to 2017. This gap was quite wide in 1976 which slightly squeezed in the following years. After 1985, gross domestic savings of Pakistan rose upward just above 15\% of GDP to maintain the investment requirement of the country as aid inflows declined in those years. This trend continued till 2002 following the foreign assistance transfers from the USA but it led to a decrease in the level of domestic savings again below 7\% (GDP ratio) in the following years. 


\section{Investment-Saving Gap in Pakistan}

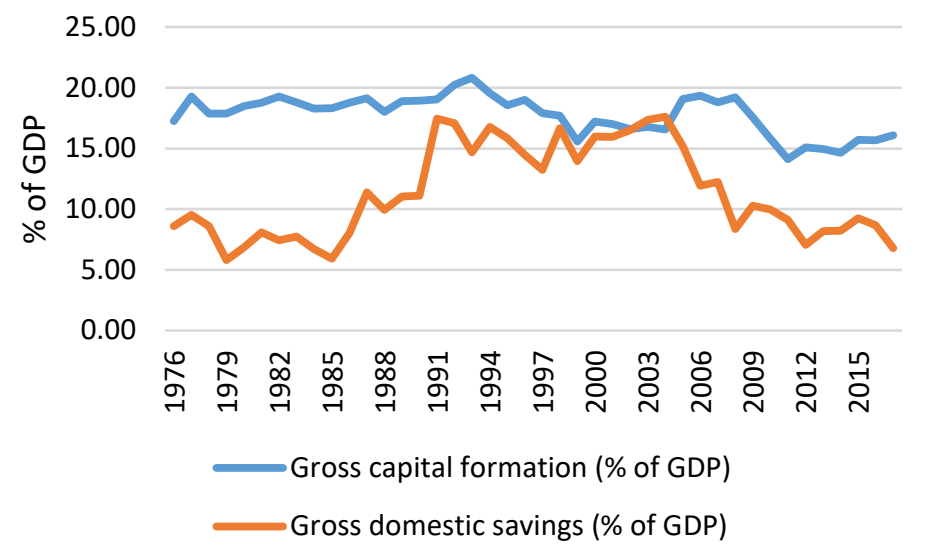

Figure 1. Investment-Saving Gap in Pakistan from1976-2017 (Data source is WDI)

\section{LITERATURE REVIEW}

Many economists believe that Foreign Aid inflows fill out the Investment-Savings Gap in the economic growth of developing countries. According to Papanek (1973), Chenery \& Strout (1966), Thirlwall (1999), Gulati (1975), Mosley (1980), Karras (2006), Hatemi \& Irandoust (2005), there is a positive relationship between foreign inflows and economic growth rate since foreign inflows supplements the domestic savings of the developing countries which are insufficient in most cases. Moreover, foreign aid facilitates the role of a bridge to lessen the gap of foreign exchange (trade gap) and it provides access to the latest technology (via imports) and technical skills, allowing easier entry to the markets of other countries.

The other strand of the literature on the Aid- Growth nexus, asserts that foreign aid does not contribute to the economic growth and other major macroeconomic parameters of the country rather it drains the domestic resources sometimes. According to this group, foreign aid does not complement the domestic resources rather it is consumed in the non-development expenditures by the inefficient and corrupt governments of the country. Bauer (1972), Friedman (1958), Boone (1996), Easterly (2000), Easterly (2003), Moyo (2009), Sethi et al (2019), Farah et al. (2017) proved the negative influence of foreign aid on the economic indicators. According to Moyo (2009, p. 28). Foreign assistance prolongs the vicious circle of poverty hence drags the economy into unsustainable growth.

The first-ever study on Pakistan's aid and growth patterns was carried out by Chenery and MacEwan (1966) which was organized in the scenario of Pakistan's 20 years' growth projections for the period of 1965-1985. According to his predictions, Pakistan would require foreign assistance beyond 1985 to fill up its two gaps; Savings-Investment Gap and Export-Import Gap.

Younis et al. (2015) attempted to examine the pattern of sustainable development in Pakistan by using the data for 1950-2013. They applied the Hicks-Page-Hartwick-Solow rule to measure sustainable development. Their study revealed that Pakistan has been on the path of unsustainable development since the 1950s. The country has faced low saving and investments that persisted the "Saving-Investment Gap" and the country remained stuck in a fiscal deficit. Investment in the physical and social infrastructure is inadequate which caused neglect of human development. No solid policies were in place to stop environmental degradation. The way forward that they suggested 
to put the country on the sustainable path, advocates the improved level of domestic savings and policy formation for the economic, social and environmental sectors.

Anwar (2014) had a critical evaluation of previous literature on foreign aid regarding Pakistan. According to his in-depth review, foreign aid does not affect the economic growth of Pakistan positively, with a significant result. In certain cases, it plays the opposite role for the economy, and evidently, it had the worst effect on the economy by hampering the growth of the social sector. It has also impacted the process of economic development as a whole, negatively. He asserted that the domestic politics of donors must be studied sufficiently. Ali and Ahmed, (2013) based on their empirical analysis suggest a dire need to decrease the dependence of the economy on foreign aid and external debt.

Malik et al. (2010) explored the case of cointegration between economic growth and external debt in the case of Pakistan. According to their findings, with the increasing external debt, the country will have lesser opportunities for economic growth. Shirazi et al. (2009) studied the impact of ODA on social development indicators of Pakistan. They used ODA for the foreign aid while the explanatory variables include indexes for economic growth, Education, Human development, health and life expectancy. A bidirectional causality was reported between ODA and economic growth. Similarly, causality runs from Foreign Aid to Human Development (HDI), Life Expectancy Index, and Education Index.

Foreign aid study conducted by Salman and Hui (2009) attempts to review the usefulness of foreign aid on the economic development of Pakistan. The period of the study was 30 years (19782007). The authors used GDP as a proxy variable for Economic development and ODA and foreign debt as independent variables narrowing down to the impact of ODA and debt on GDP growth of Pakistan for the target period. Their study findings of aid effectiveness for Pakistan is significantly promising and positive.

Khan and Ahmed (2007) examined the relationship of aid and growth on annual data for the period of 1972 to 2006 and applied the ARDL approach. Variables of Domestic Investment and Foreign Direct Investment and Foreign Assistance were taken as explanatory variables with real GDP (Y) as a dependent variable. They extended the production function called adding factors of Aid and Exports along with Capital and Labour. F Bound test was significant for all types of Aid, claiming a co-integration between Aid and GDP but their conclusion suggest that Aid flows do not influence Growth, neither at aggregate level nor disaggregate level.

Muhey-u-din (2005) advocates the Dual Gap Model of Chenery through his study and justifies the need for foreign inflows in the case of Pakistan. According to him, Pakistan has to rely on foreign aid and foreign debt since it does not have physical, financial \& human capital.Khan (1997) finds out that the terms and conditions of foreign aid and loans used to be harsher when a country becomes dependent on foreign aid to finance domestic investment and fill out BOP deficits. Their study results find that foreign aid/flows have a negative and significant coefficient, irrespective of the use of conditioning variables.

\section{METHODOLOGY}

The most credible source of a theoretical base for the research subject is provided by the all-time renowned model of Economic Growth.

According to Harrod-Domar theory; $\mathbf{g}=\mathbf{s} / \mathbf{k}$ where $\mathrm{g}$ is the growth rate of GDP, $\mathrm{s}$ represents Savings and $\mathrm{k}$ is Capital Output Ratio.

And to increase the rate of investment requires a higher rate of capital accumulation and an enhanced level of capital formulation demands a relative increase in the domestic savings. The 
Harrod Domar Model is a Keynesian Model of economic growth which explains what rate of investment growth is required to keep the economy on a steady path of development.

Chenery and Strout (1966), extending the Harrod Domar Growth Model for a two-sector economy, developed the Tow Gap Model i-e 'Investment-Saving Gap' and 'Import-Export Gap' to achieve the optimal patterns of economic growth. The excess of the traditional import over the traditional exports less the production for the trade sector leads to Trade Gap and developing countries have to rely on foreign resources if they don't have enough domestic savings. (Chenery \& MacEwan, 1966) This study will focus to answer the below questions primarily:

- Is there any relationship between Official Development Assistance and Sustainable Development of Pakistan?

- What is the nature of the relationship between ODA and sustainable development? Is there any long-run co-integration between both variables?

- What is the impact magnitude of ODA on sustainable development in Pakistan?

The below equation has been developed to conduct the empirical examination of our research hypothesis.

$$
S D=f(O D A+G D P P C+I N F+T R D O)
$$

SD stands for Sustainable Development being a dependent variable in the study. Variable of Adjusted Net Savings (\% of GNI) formerly called Genuine Savings has been deployed as a measure the Sustainable Development. ODA represents Official Development Assistant (\% of GNI). GDPPC represents GDP Per Capita for Pakistan (Current US \$).

INF is the Inflation (Consumer Prices, Annual \%) variable which is taken as a monetary policy measure on the pattern of Rana and Koch (2020), Fischer (1993) and Burnside \& Dollar (2000). TRDO measures Trade Openness Rana and Koch (2020) for which we have taken annual data of Trade (\% of GDP) following Sachs and Warner (1995) and Burnside and Dollar (2000).

The econometric form of the equation will be:

$$
S D=\beta_{0}+\beta_{1} O D A+\beta_{2} G D P P C+\beta_{3} I N F+\beta_{4} T R D O+\mu
$$

The below hypothesis has been built to investigate through this study. Here, $\mathrm{H}_{0}$ represents Null Hypothesis while $\mathrm{H}_{\mathrm{A}}$ shows the alternative hypothesis. $\mathrm{B} 1$ is the slope coefficient of ODA.

$$
\mathrm{H}_{0}: \beta_{1}=0 \quad \mathrm{H}_{A}: \beta_{1} \neq 0
$$

For this study, the time-series data of 42 years (1976-2017) has been obtained by using different relevant and authentic sources including World Development Reports, World Development Indicators, OECD Reports and Pakistan Economic Surveys.

\section{DISCUSSION}

Since ARMA models for the non-stationary data, all data series needs to be tested for stationarity. The augmented Dickey-Fuller test is considered the most authentic test to check the stationarity (Dickey \& Fuller 1979, Brooks 2014)

In table 01, the variables have mix order of integration which means that some variables are of $\mathrm{I}(0)$ and some of them are I(1), which makes the Autoregressive Distributed Lag approach the most feasible for the empirical analysis. 
Table 1. Result of Augmented Dickey Fuller Test

\begin{tabular}{|c|l|l|c|c|c|}
\hline Variable & Description & Model & Level & 1st & Variable \\
\hline ANS & Adjusted Net Savings & Intercept & -3.631 & & $\mathrm{I}(0)$ \\
\hline ODA & Official Development Assistance & Intercept & -5.41 & & $\mathrm{I}(0)$ \\
\hline GDPPC & Per Capita GDP & Intercept & 2.46 & -4.977 & $\mathrm{I}(1)$ \\
\hline INF & Inflation, CPI & Intercept & -4.51 & & $\mathrm{I}(0)$ \\
\hline TRDO & Trade & Intercept & -2.051 & -7.278 & $\mathrm{I}(1)$ \\
\hline
\end{tabular}

ARDL method is OLS based which consists of lags of both, dependent and independent variables. The main usage of this method is that it permits the testing of the cointegration irrespective of the degree of variables. This approach is more valid than the Johansen-Juselius approach when the sample size is small. Hence, adding the component of Time (t) and lags of dependent and explanatory variables we will convert the equation (b) into Autoregressive Lagged Distributed Model;

$$
S D_{t}=\beta_{0}+\beta_{1} S D_{t-i}+\beta_{2} O D A_{t-i}+\beta_{3} G D P P C_{t-i}+\beta_{4} I N F_{t-i}+\beta_{5} T R D O_{t-i}+\varepsilon_{t i}
$$

Model of $(2,3,4,0,0)$ was selected as Optimal model along with Adjusted R Square of 0.67 and value of F.stat at 6.8. Akaike info criterion (AIC) was used for the lag selection method. Lag of 4 was used which is considered the optimal lag period for the annual data series. ARDL Bound Test is applied to find out long run cointegration among variables which converts the above equation into the below form:

$$
\begin{gathered}
\Delta S D=\beta 0+C 0_{t} \sum_{j=1}^{q} \alpha \Delta S D_{t-j}+\sum_{i=0}^{p} \gamma \Delta O D A_{t-i}+\sum_{i=0}^{n} \pi \Delta G D P P C_{t-i}+\sum_{i=0}^{m} \delta \Delta I N F_{t-i}+ \\
\sum_{i-=}^{k} \lambda \Delta T_{R D O} \boldsymbol{t}_{t-i}+\Phi_{1} S D_{t-1}+\Phi_{2} O D A_{t-1}+\Phi_{3} G D P P C_{t-1}+\Phi_{4} I N F_{t-1}+\Phi_{5} T_{R D O} o_{t-1}+\epsilon_{t}
\end{gathered}
$$

Here, $\mathrm{B} 0$ is the drift component while $\mathrm{C}_{\mathrm{t}}$ is the Trend component. Parameters like $\alpha, \gamma, \pi, \delta, \lambda$ are short term coefficients hence will represent short-run relationships while $\Phi_{1}, \Phi_{2}$,

\begin{tabular}{|c|c|c|c|c|}
\hline \multicolumn{2}{|l|}{ F-Bounds Test } & \multicolumn{3}{|c|}{$\begin{array}{l}\text { Null Hypothesis: } \\
\text { relationship }\end{array}$} \\
\hline Test Statistic & Value & Signif. & $\mathbf{I}(\mathbf{0})$ & $\mathbf{I}(\mathbf{1})$ \\
\hline F-statistic & 6.539848 & $10 \%$ & 2.427 & 3.395 \\
\hline $\mathbf{k}$ & 4 & $5 \%$ & 2.893 & 4 \\
\hline $\mathrm{N}=40$ & & $1 \%$ & 3.967 & 5.455 \\
\hline
\end{tabular}
$\Phi_{3}, \Phi_{4}, \Phi_{5}$ are long term coefficients telling long-run relationships among variables

Table 2. Result of F-Bound Test

F-Bound Test is quite significant as the calculated value of F-statistics is 6.539 and this value is larger than upper boundary values. The Null Hypothesis of "No Cointegration" may be rejected and the Alternative Hypothesis can be accepted easily. This rejection of the Null Hypothesis confirms the long-run cointegration between dependent and independent variables. Therefore, further exploration of the relationship dynamics can be justified for which Error Correction Regression was run to check the significance and magnitude level of this long-run relationship. 
Table 3. Long Run

\begin{tabular}{|c|l|l|l|l|}
\hline Variable & Coefficient & Std. Error & t-Statistic & Prob. \\
\hline ODA & 4.422286 & 0.721114 & 6.132577 & $0.0000^{*}$ \\
\hline GDPPC & 0.003943 & 0.002207 & 1.786338 & $0.0867^{* * *}$ \\
\hline INF & -0.329015 & 0.119315 & -2.757527 & $0.0110^{* *}$ \\
\hline TRDO & -0.244595 & 0.181319 & -1.348980 & 0.1899 \\
\hline C & 12.46772 & 6.219343 & 2.004669 & 0.0564 \\
\hline
\end{tabular}

Table 04 shows that the long-run coefficient of ODA becomes positive and double in magnitude in the long run period, from -2.09 to 4.422 which is positive and significant with t-stats of 6.13 and a p-value of 0.000. It can be concluded that if 1-point increases in ODA it will lead to an increase in the Adjusted Net Savings by 4 points. On the other hand, the variable of inflation (INF) puts a negative impact on Adjusted Net Savings in the long run. One point increase in inflation will cause the reduction in the Adjusted Net Savings by 0.32 points. It can be noticed that variables of GDP Per Capita (GDPPC) and Trade Openness (TRDO) becomes insignificant on their impact on the Adjusted Net Savings. However, although both variables are insignificant, growth in GDP per capita has a positive coefficient while TRDO shows a negative relationship with the dependent variable.

The dynamics Error Correction Model estimated through Error Correction Regression provides the cointegrating equation $\left(\mathrm{EC}_{\mathrm{t}-1)}\right.$ which integrates the short-run dynamics with long-run equilibrium.

$$
\begin{aligned}
& \Delta S D_{t}=0.21 \Delta S D_{t-1}+0.49 \Delta O D A-2.35 \Delta O D A_{t-1}-2.09 \Delta O D A_{t-2}+0.001 \Delta G D P P C \\
& \text { (1.72) (1.25) } \quad(-3.87)^{*} \quad(-4.18)^{*} \quad(0.47) \\
& -0.001 \Delta \text { GDPPC }_{\mathrm{t}-1}-0.004 \Delta \mathrm{GDPPC}_{\mathrm{t}-2}+0.016 \Delta \mathrm{GDPPC}_{\mathrm{t}-3}-0.295220 \Delta \mathrm{INF} \\
& \begin{array}{llll}
(-0.35) & (-0.81) & (2.96) * & (0.0298)
\end{array} \\
& -0.219 \Delta \text { TRDO }-0.89 \mathrm{EC}_{\mathrm{t}-1} \\
& \text { (0.1539) } \quad(-6.88)^{*} \\
& R^{2}=0.72 \quad \text { Adj. } R^{2}=0.65 \quad \text { F-Stats. } 6.54 \quad S S R=64.69
\end{aligned}
$$

The above equation confirms the short-run causality of ODA with SD in the first lag and second lag period as significant $t$ values are tagged with steric $\left(^{*}\right)$ sign. The speed of adjustment measures the time required to bring the model in equilibrium while it falls in the state of disequilibrium. In other words, it confirms the convergence of the model towards equilibrium. The below equation is called the Cointegration Equation.

$$
\Delta S D_{t}=-0.89 S D_{t-1}-\left\{\left(4.42 O D A_{t-1}+0.003 G D P P C_{t-1}-0.329 I N F_{t}-0.24 T R D O_{t}+12.46\right)\right\}
$$

Term of Co-integrating Equation $\left(\mathbf{E C}_{\mathbf{t}-1}\right)$ indicates the speed of adjustment. Its value falls between 0 and 1 . The negative sign with the value suggests that the model is convergent or getting stable. On the other hand, a positive sign with the value of this term indicates that the model is divergent or explosive and it moves towards disequilibrium in the long run. Here, as we can see, the value of the Co-integration Equation is $\mathbf{- 0 . 8 9}$ being significant with a t-value of $\mathbf{- 6 . 8 8}$ and $\mathrm{P}$ value less than0.05 providing a base to conclude that model is stable and convergent towards equilibrium.

RESIDUAL NORMALITY: Jarque Bera value $=0.367 \quad$ P value $=0.832$ 


\section{LM SERIAL CORRELATION: F-statistic $=0.259224 \quad$ Prob.F $(4,20)=0.9006$}

MODEL STABILITY TEST: Ramsey RESET is a general misspecification error test. It verifies if there is any specification error in the fitted model. The below graphs of CUSUM and CUSUM Square tests also confirm the model stability.

Table 4. Result of Ramsey

\begin{tabular}{|l|c|c|}
\hline & Value & Probability \\
\hline t-statistic & 0.946134 & 0.3539 \\
\hline F-statistic & 0.895170 & 0.3539 \\
\hline Likelihood ratio & 1.450921 & 0.2284 \\
\hline
\end{tabular}

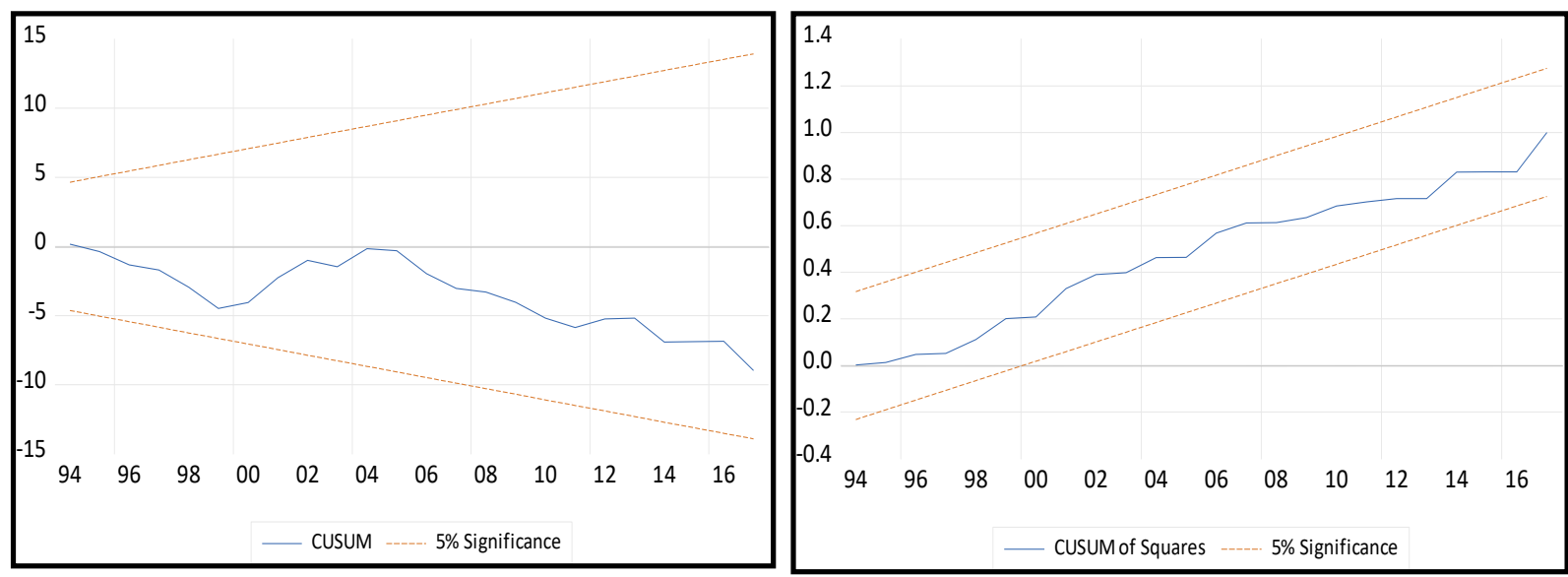

\section{CONCLUSION AND RECOMMENDATIONS}

This study explores the impact of Official Development Assistance on the Sustainable development of Pakistan for the period of 1976-2017. The result of this study reveals that ODA has a positive and significant impact on the Sustainable Development of Pakistan, in the long run. The results of the Augmented Dickey-Fuller showed that some variables are stationary at a level while others were stationary at first difference. That suggested application of the ARDL and VEC model to conduct the empirical analysis of the data through econometric models. The significance of the Bounds Test and slope coefficient (4.422) of ODA in the long run with the significant t stats (6.13) and p values $(<0.05)$ provides enough evidence of the robust positive relationship between ODA and the measure of Sustainable Development of Pakistan. Empirical evidence shows that 1 point increase in ODA, in the long run, leads to bringing increment of 4.42 points in the Sustainable Development of Pakistan for which the variable of Adjusted Net Savings was taken. Additionally, we found that 1 point increase in the level of inflation will decline the level of sustainable development by 0.32 point. The variable of GDP per capita has positive and significant causality with sustainable development in its 4th lag year in low magnitude. The variable of Trade Openness turns out to be negative but insignificant, in short as well as long-run periods. Based on the above results, a few recommendations have been put forward for all of the Aid-concerned Government Authorities and development professionals (NGOs, INGOs etc.) in Pakistan.

- As Pakistan does not have enough internal sources to finance the large investment projects, Government spending on human welfare programs and the conservation of natural resources Pakistan would have to rely on Foreign Assistance subject to the transparent and efficient 
practices applied in the Aid Allocation. Although Aid funds are prone to fungibility their flows are healthy for sustainable development in Pakistan (Rana \& Koch, 2020). Aid will help increase the level of Sustainable Development by supplementing the domestic savings in the country. Proper allocation of Aid funds in Mega Development Projects for Education, Health and Environment Conservation will significantly improve the level of overall social welfare in Pakistan.

- A higher level of inflation needs to be controlled immediately because it cannot only hit the country on economic grounds but also humanitarian spheres. A high level of inflation may worsen the living standard of people.

- Following Younis, Chaudhary, \& Akbar (2015) who suggested that low index of sustainable development in Pakistan can be increased by increasing the level of domestic savings in the country, this study also recommends that Government, as well as people of the country, must decline their consumption on unsustainable and unproductive plans.

\section{REFERENCES}

Ali, S., \& Ahmed, N. (2013). A Time Series Analysis of Foreign Aid and Income Inequality in Pakistan. Global Journal of Management and Business Research

Anwar, M. (2007). Foreign Aid to Pakistan: A Critical Evaluation. http://www.jstor.org/stable/41501694.

Asongu, S. A., \& Nnanna, J. (2018). Foreign aid and sustainable inclusive human development in Africa. DBN Journal of Economics and Sustainable Growth.

Basnet, H. (2013, November). Foreign Aid, Domestic Savings, And Economic Growth In South Asia. International Business \& Economics Research Journal, 12, 3-6.

Boulanger, P. (2008). Sustainable development indicators: a scientific. OpenEdition Journals, 1014.

Chenery, H. B., \& MacEwan, A. (1966). Optimal Patterns of Growth and Aid The Case of Pakistan. The Pakistan Development Review.

Chenery, H. B., \& Strout, A. M. (1966). Foreign assistance and economic development. American Economic Reveiw, 679-733.

Combes, J.-L., Kinda, T., Plane, P., \& Ouedraogo, R. (2019). Financial flows and Economic growth in developing countries. Economic Modelling 83.

Edwards, S. (2015, August). Economic Development and the Effectiveness of Foreign Aid: A Historical Perspective. Kyklos: International Review of Social Sciences, 68(3), 277-316. doi:https://doi.org/10.1111/kykl.12084

Emas, R. (2015). The Concept of Sustainable Development: Definition and Defining Principles. Florida International University.

Ezaki, M. (1975). On the Two-Gap Analysis of Foreign Aid. Journal of Southeast Asian Studies. 
Hamilton, K. (2000, October). Genuine Saving as a Sustainability Indicator. Environment Department Papers, 22744, The World Bank.

Hussain, I. (2005, May 20th). Lecture delivered at No. 18 Air War Course at PAF Air War College, Karachi. National Economy and Impact of Foreign Aid. Karachi, Sindh, Pakistan: Institute of Business Administration.

Irandoust, M., \& Erricson, J. (2005). Foreign aid, domestic savings and growth in LDCs: An Application of Likelihood-based panel cointegration. Economic Modelling, 616-627.

Katharine, Bolt; Mampite, Matete; Michael Clemens;. (2002). Manual for Calculating Adjusted Net Savings. Washington DC: Environment Department, World Bank.

Khan, M. A., \& Ahmed, A. (2007). Foreign Aid-Blessing or Curse: Evidence from Pakistan. The Pakistan Development Review, 46, 215-240.

Khan, M., \& Ahmed, A. (2007). Foreign Aid-Blessing or Curse: Evidence from Pakistan. The Pakistan Development Review.

Khan, N., \& Rahim, E. (1993). Foreign Aid, Domestic Savings and Economic Growth (Pakistan: 1960 to 1988). The Pakistan Development Review, 1157-1167.

Khan, S. R. (1997). Has Aid Helped in Pakistan? The Pakistan Development Review, 4-5.

Lohani, S. (2004). Effect of Foreign Aid on Development: Does More. Illinois USA: Digital Commons, Illinois Wesleyan University.

Mahembe, E., \& Odhiambo, N. M. (2019). Foreign aid and poverty reduction: A review of international literature. Cogent Social Sciences.

Malik, S. J., Hussain, M., \& S.Sherazi, N. (1994). Role of Infaq in Poverty Alleviation in Pakistan. The Pakistan Development Review.

Malik, S., Hayat, M. K., \& Hayat, M. U. (2010). External Debt and Economic Growth: Empirical. International Research Journal of Finance and Economics.

Michel, J. (2016). Beyond Aid-The integration of Sustainable Development in the Coherent International Agenda. The Center for Strategic and International Studies. Lanham: ROWMAN \& LITTLEFIELD .

Mohey-ud-din, G. (2005). Impact of Foreign Aid on Economic Development in Pakistan (19602002). Munich Personal RePEc Archive.

Papanek, G. F. (1973). Aid, Foreign Private Investment, Savings, and Growth in Less Developed Countries. Journal of Political Economy.

Pillarisetti, J. R. (2005). The World Bank's genuine savings measure and sustainability. Elsevier, 13. 
Radelet, S. (2006). A Premier on Foreign Aid. Centre for Global Development.

Rana, Z., \& Koch, D. (2020). Why fungibility of development aid can be good news: Pakistan case study. World Development Perspectives. doi:https://doi.org/10.1016/j.wdp.2020.100248

Salman, A., \& Hui, X. F. (2009). Three Decades and More of Foreign Aid in Pakistan: Impact on GDP. Conference Paper.

Sen, A. (1988). The Concept of Development. In S. T. Chenery H, Handbook of Development Economics (pp. 1-18). Amsterdam: North Holland .

Williams, M. (2016). Aid, sustainable development and the environmental crisis. The International Journal of Peace Studies.

Younis, F., Chaudhary, M. A., \& Akbar, M. (2015). Pattern of Development and Sustainable Economic Growth in Pakistan; A descriptive Analysis. Munich Personal RePEc ArchiveMPRA.

\section{Copyrights}

Copyright for this article is retained by the author(s), with first publication rights granted to the journal. This is an open-access article distributed under the terms and conditions of the Creative Commons Attribution license (http://creativecommons.org/licenses/by/4.0) 